\title{
Imagined and Imaginary Whales: George Orwell, Benedict Anderson and Salman Rushdie
}

\author{
NICK HUBBLE, \\ UNIVERSITY OF CENTRAL ENGLAND, UK \\ nick.hubble@uce.ac.uk
}

Abstract: George Orwell, anticipating many of the arguments made by Benedict Anderson in the 'Patriotism and Racism' chapter of Imagined Communities, illuminated patriotism and nationalism as shifting aspects of a wider dialectical interplay between an identification with imagined communities and a loyalty to humanity. Orwell's essay "Inside the Whale" can be seen, contrary to Salman Rushdie's criticism that it advocates quietism, as an essay about imaginary homelands. In this reading the whale is a metaphor for a dialectical space created by a writer in order to gain purchase on the unceasing dialectic of history. Analysis of The Lion and the Unicorn in this article links Orwell's work with that of Anderson and Rushdie by exploring in his vision of a classless England the relationship between the personal imaginary homeland and the political imagined community.

Keywords: Class, Literature, Nationalism, Patriotism, Tropical Gothic.

In The Lion and the Unicorn (1941), George Orwell argues that the patriotism of the common people is neither jingoistic nor militaristic, as exemplified by the fact that the most celebrated poems, such as Charles Wolfe's “The Burial of Sir John Moore after Corunna", are about defeats. Five verses of Wolfe's poem are quoted by Benedict Anderson in Imagined Communities in order to illustrate how the imagined community of the English is both open to others through its shared learnable language - Moore and Wolfe were Irish - and closed by its relationship to "historical fatality" (146). That is, the English dead, rather than being left to bury themselves, are constantly invoked as shadowy presences who serve to define an England that cannot be changed because it is historically fixed. According to Anderson, this is not to rule out the possibility of naturalisation but to ensure that English identity is fixed in such a way that newcomers can never change it.

"Patriotism and Racism" is the chapter of Imagined Communities in which this is discussed, although the text is actually contrasting nationalism with racism. The effect 
of this in a book specifically about nationalism is to associate patriotism with racism. Thus the openness of the "imagined community" and the positive value of selfsacrificial love is equated with nationalism; while the closed nature of the traditional community is equated with patriotism and racism: "The fact of the matter is that nationalism thinks in terms of historical destinies, while racism dreams of eternal contaminations, transmitted from the origins of time through an endless sequence of loathsome copulations: outside history" (149). Racism is associated with the same eternal nature as the immutable patriotism of the dead. In fact, we are told, racism and, by implication, patriotism - are functions of class, operating to maintain internal domination by means of overseas expansion:

It [colonial racism] did so by generalising a principle of innate, inherent superiority on which its own domestic position was (however shakily) based to the vastness of the overseas possessions, covertly (or not so covertly) conveying the idea that if, say, English lords were naturally superior to other Englishmen, no matter: these other Englishmen were no less superior to the subjected natives. (150)

This was assisted by the opportunity colonialism presented for its bourgeois and petty bourgeois participants to live like lords. The quotation that Anderson uses to illustrate this point is strangely familiar:

In Moulmein, in lower Burma [this obscure town needs explaining to readers in the metropole], I was hated by large numbers of people - the only time in my life that I have been important enough for this to happen to me. I was a sub-divisional police officer of the town. (151) 
This is, of course, the opening of Orwell's "Shooting an Elephant", which Anderson acknowledges with a footnote. However, in the main body of his text, Anderson does not mention Orwell and simply labels the extract "tropical Gothic", presumably implying that it tells us more about English fantasy than Burmese reality. What Anderson fails to acknowledge is that "Shooting an Elephant" is an anti-imperialist text. To be sure, as John Coombes has noted, the allegory of imperialism it provides can be read on one level as carrying "a strong charge of right-wing pessimism and elegy" (Coombes 252). However, as Coombes goes on to demonstrate, Orwell's conscious manipulation of interplaying parodies works to expose not only the "fraudulence of imperialist performance" but also the "fraudulence of the performance of writing imperialism" (254). In other words, the reason why Anderson finds Orwell such a convenient medium for exposing the class-based operations of colonialism is that Orwell was himself intent on exposing those same operations by means of parodying them. In this context, Edward Said's Orientalism provides a more useful model for the postcolonial critic wishing to use Orwell to illustrate the colonial mindset. As part of his demonstration of how Orientalism was transformed from a specialist nineteenth-century discipline into one of the mainsprings of twentiethcentury European cultural consciousness, Said cites a passage from Orwell's essay “Marrakech" (1939):

... when you see how the people live, and still more, how easily they die, it is always difficult to believe that you are walking among human beings. All colonial empires are in reality founded upon that fact. The people have brown faces - besides they have so many of them! Are they really the same flesh as yourself? Do they even have 
names? Or are they merely a kind of undifferentiated brown stuff, about as individual as bees or coral insects? (252 [CW XI 417])

This allows Said both to expose common forms of individual prejudice and to make the more general point that colonialism operated by allowing its subjects to be seen only 'as a kind of continental emanation' (251). Thus, he is able to conclude:

... the non-European known to Europeans is precisely what Orwell says about him. He is either a figure of fun, or an atom in a vast collectivity designated in ordinary or cultivated discourse as an undifferentiated type called Oriental, African, yellow, brown, or Muslim. (252)

Said avoids implying that Orwell shares this colonial viewpoint by properly acknowledging him and quoting a passage sufficiently long to show that Orwell gives voice to such prejudices through an act of literary ventriloquism that is sharply differentiated from his normal narrative tone. Viewed in this light, Orwell's work is not only an illustrative tool but also, as this extract suggests, a forerunner of postcolonial theory in its conscious criticism of the dualism within Eurocentric universalism which enabled the Western visitor to view the East as simultaneously exotic spectacle and homogenous mass. Furthermore, Orwell carefully situated the origins of this dualism within European class society. For example, Anderson's point about colonialism permitting "sizeable numbers of bourgeois and petty bourgeois to play aristocrat off centre court" (150) was originally made by Orwell in The Road to Wigan Pier (1937): 
To belong to [the upper-middle] class when you were at the $£ 400$ a year level was a queer business, for it meant that your gentility was almost purely theoretical. You lived, so to speak, at two levels simultaneously. Theoretically you knew all about servants and how to tip them, although in practice you had one or, at most, two resident servants. Theoretically you knew how to wear your clothes and how to order a dinner, although in practice you could never afford to go to a decent tailor or a decent restaurant. Theoretically you knew how to shoot and ride, although in practice you had no horses to ride and not an inch of ground to shoot over. It was this that explained the attraction of India (more recently Kenya, Nigeria, etc.) for the lowerupper-middle class. The people who went there as soldiers and officials did not go there to make money, for a soldier or an official does not make money; they went there because in India, with cheap horses, free shooting, and hordes of black servants, it was so easy to play at being a gentleman. ( $C W \mathrm{~V} 115)$

Orwell repeatedly emphasised these points precisely because they showed the link between the Empire and the domestic class system, and he consistently attacked both. It is also worth remembering that he considered colonialism to be a "far vaster injustice" than fascism (CW XI 360) and that this was one source of his criticism of simplistic anti-fascist or Popular-Front politics in the late 1930s. These factors have to be taken properly into account before any criticism can be made of his celebration of social patriotism and Englishness in The Lion and the Unicorn. In particular, it is necessary to consider his not inconsiderable theoretical writings on questions of patriotism and nationalism.

The position adopted by Orwell in the 1940 essay, "Notes on the Way", clearly anticipates Anderson: "Racialism [...] has nothing to do with nationalism". However, 
Orwell argues that rather than being the product of domestic feudalism, racialism is the source of that feudalism. Thus, English feudalism resulted from the Norman conquest of the Saxons: "There are traces of the Norman predominance in our language to this day. And it is much easier for the aristocrat to be ruthless if he imagines that the serf is different from himself in blood and bone" ( $C W$ XII 122). Against this, nationalism was - "up to a point" - perfectly understandable as a defence of conquered countries. This seems surprisingly different from Orwell's later trenchant views on nationalism expressed in the 1945 essay "Notes on Nationalism":

By "patriotism" I mean devotion to a particular place and a particular way of life, which one believes to be the best in the world but has no wish to force upon other people. Patriotism is of its nature defensive, both militarily and culturally. Nationalism, on the other hand, is inseparable from the desire for power. The abiding purpose of every nationalist is to secure more power and more prestige, not for himself but for the nation or other unit in which he has chosen to sink his own individuality. (CW XVII 142)

It can be seen that what was described as nationalism in spring 1940 is regarded as patriotism in 1945 , while the term nationalism has seemingly been applied to the totalitarian forms of consciousness that Orwell was to explore in Nineteen EightyFour (1949). This leaves open the question of what Orwell meant by patriotism in 1940. In the second half of "Notes on the Way", Orwell is concerned with the inevitability of a collectivist form of society: "The only question is whether it is to be founded on willing co-operation or on the machine gun" ( $C W$ XII 125). His answer demonstrates his thinking at the time: 
Men die in battle - not gladly, of course, but at any rate voluntarily - because of abstractions called "honour", "duty", "patriotism" and so forth.

All this really means is that they are aware of some organism greater than themselves, stretching into the future and the past, within which they feel themselves to be immortal. "Who dies if England live?" sounds like a piece of bombast, but if you alter "England" to whatever you prefer, you can see that it expresses one of the main motives of human conduct. People sacrifice themselves for the sake of fragmentary communities - nation, race, creed, class - and only become aware that they are not individuals in the very moment when they are facing bullets. A very slight increase in consciousness, and their sense of loyalty could be transferred to humanity itself, which is not an abstraction. (CW XII 125-6)

As Orwell goes on to acknowledge indirectly, he has taken Marx's equation "Religion is the sigh of the soul in a soulless world. Religion is the opium of the people" - and substituted "patriotism" for "religion". The implication is that "patriotism" has for Orwell the same dialectical sense that Marx gave to "religion". This dialectical sense of patriotism can be seen to underpin The Lion and the Unicorn which incorporates a number of phrases directly from the earlier essay, for example: "[English Civilisation] is continuous, it stretches into the future and the past, there is something in it that persists, as in a living creature" (CW XII 393). However, by 1945 Orwell had to accept that the English revolution proclaimed in The Lion and the Unicorn had not come to pass. In an article of that year, "The French Believe We Have Had a Revolution", he was quick to identify the problem: "The mistake made, in many cases, seems to be to confuse patriotism with social enlightenment" ( $C W \mathrm{XVII}$ 
94). Once again the opium of the people had proved stronger in the short term than the sigh of the soul in a soulless world.

It was this disappointment which led directly to the more restrictive definition of patriotism that we have seen Orwell to adopt in "Notes on Nationalism". For while he appears to advocate patriotism - "It can plausibly be argued, for instance - it is even probably true - that patriotism is an inoculation against nationalism, that monarchy is a guard against dictatorship" - by the end of the essay he clearly designates and rejects this train of thought "as a species of Conservatism" ( $C W$ XVII 142). By the same token, his definition of "nationalism" is not as unrelentingly negative as it appears from the passage quoted earlier. Indeed, there the term "nationalism" appears to have become synonymous with the dominant Western post-war negative conception of nationalism against which Anderson's book was a timely reaction. However, as the essay progresses, Orwell admits that he is not using the word in its accepted sense but as an extended term to cover a variety of movements from Communism to Catholicism. In short, the dialectical sense that Orwell had applied to "patriotism" in 1940 had now been transferred to "nationalism" with the result that, despite the evident tone of distaste, he is actually arguing in "Notes on Nationalism" for a complex acceptance of nationalism:

I think one must engage in politics - using the word in a wide sense - and that one must have preferences: that is, one must recognise that some causes are objectively better than others, even if they are advanced by equally bad means. As for the nationalistic loves and hatreds that I have spoken of, they are part of the make-up of most of us, whether we like it or not. Whether it is possible to get rid of them I do not know, but I do believe that it is possible to struggle against them, and that this is 
essentially a moral effort. It is a question first of all of discovering what one really is, what one own's feelings really are, and then of making allowance for the inevitable bias. If you hate and fear Russia, if you are jealous of the wealth and power of America, if you despise Jews, if you have a sentiment of inferiority towards the British ruling class, you cannot get rid of these feelings simply by taking thought. But you can at least recognise that you have them and prevent them from contaminating your mental processes. The emotional urges which are inescapable, and are perhaps even necessary to political action, should be able to exist side by side with an acceptance of reality. (CW XVII 155)

Orwell's rejection of his own potential polar division between patriotism and nationalism - into defensiveness and desire for domination - has implications for Anderson's distinction between a closed patriotism and an open nationalism. While such rigid categorisations can be used to generate illuminating analysis, they do not reflect the messy realities of the political world. The trajectory of Orwell's thought from 1940 to 1945 illuminates patriotism and nationalism as shifting aspects of a wider dialectical interplay between identification with imagined communities and loyalty to humanity. A crude Marxism - but not, of course, Marx himself - would attempt to separate these two into false consciousness and authenticity. Orwell did not fall into this trap and instead employed his dialectical understanding towards changing the world rather than merely theoretically describing it.

From this perspective on Orwell, the account of him provided by Rushdie in "Outside the Whale" is simply unrecognisable. Writing in 1984 about the spate of books and films set in the British Raj (notably Paul Scott's Raj Quartet and David Lean's film of A Passage to India), Rushdie connects the revival of colonial 
stereotypes with Margaret Thatcher's post-Falklands declaration that 'the British were still the people "who had ruled a quarter of the world" (92). He then links this to “1984's other literary phenomenon, Mr Orwell” (93) - not in terms of a shared colonial viewpoint, but by claiming that there is a linked strand of pessimism and quietism running through Orwell's work from "Inside the Whale", published in 1940, to Nineteen Eighty-Four published in 1949: "the truth is that passivity always serves the interests of the status quo, of the people already at the top of the heap, and the Orwell of "Inside the Whale" and Nineteen Eighty-Four is advocating ideas that can only be of service to our masters" (97). In rejecting passivity as directly enabling the British and American neo-colonial ventures of the 1980s, Rushdie makes a trenchant case for politically engaged writing:

The modern world lacks not only hiding places, but certainties. There is no consensus about reality between, for example, the nations of the North and of the South. What President Reagan says is happening in Central America differs so radically from, say, the Sandinista version, that there is almost no common ground. It becomes necessary to take sides, to say whether or not one thinks of Nicaragua as the United States's "front yard". (Vietnam, you will recall, was the "back yard".) It seems to me imperative that literature enter such arguments, because what is being disputed is nothing less than what is the case, what is truth and what untruth. If writers leave the business of making pictures of the world to politicians, it will be one of history's great and most abject abdications. (100)

I would suggest that this passage evokes no other twentieth-century writer so much as it does Orwell, who disputed truth and untruth with sufficient unflagging commitment 
to leave probably the most rancorously disputed reception history of any major literary figure. Return to the first line of the passage from "Notes on Nationalism" quoted above and one finds it clearly stated: "I think one must engage in politics". This was in 1945 and so in itself provides one point of contradiction to Rushdie's argument that Orwell was a quietist from 1940 onwards. However, given the persistence of distorted accounts of Orwell, it is useful to show by means of a close reading why Rushdie misreads Orwell in general and "Inside the Whale" in particular. Rushdie's argument concerning "Inside the Whale" can be split into several points, which can be taken in turn. He criticises Orwell for attacking "the politically committed generation of Auden, Spender and MacNiece. “ 'On the whole,' Orwell says, 'the literary history of the thirties seems to justify the opinion that a writer does well to keep out of politics" " (94). On this point, historical context is all important. The fact is that Auden renounced his political commitment before, or more correctly during, the writing of "Inside the Whale" and Orwell knew about this as is demonstrated by his comments: "Neither Auden nor, on the whole, Spender wrote about the Spanish war in quite the vein that was expected of them. Since then there has been a change of feeling and much dismay and confusion, because the actual course of events has made nonsense of the left-wing orthodoxy of the last few years" ( $C W$ XII 105). Immediately following this passage is the observation: "On the whole the literary history of the 'thirties seems to justify the opinion that a writer does well to keep out of politics." When not wrenched out of context, this can be seen for what it is: an ironic comment on the "change of feeling" undergone by the Auden group. It fact, it is almost certainly directed specifically at the opening lines of Auden's “September 1, 1939”, first published in America in New Republic in October 1939: 
I sit in one of the dives

On Fifty-Second Street

Uncertain and afraid

As the clever hopes expire

Of a low dishonest decade (Auden 245)

Hence, Orwell concludes this section of his discussion: "Good novels are not written by orthodoxy-sniffers, nor by people who are conscience-stricken about their own unorthodoxy. Good novels are written by people who are not frightened. This brings me back to Henry Miller" (CW XII 105-6).

This brings us to another of Rushdie's points of criticism, that he simply cannot see any value whatsoever in the work of Henry Miller, the subject of "Inside the Whale": "In the forty-four years since the essay was first published, Miller's reputation has more or less completely evaporated, and he now looks to be little more than the happy pornographer beneath whose scatological surface Orwell saw such improbable depths" (95-6). The answer to this point is that Orwell advocates Miller because he wrote about everyday life and got closer to the ordinary man than more "purposive" writers:

For the ordinary man is also passive. Within a narrow circle (home life, and perhaps the trade union and local politics) he feels himself master of his fate, but against major events he is as helpless as against the elements. So far from endeavouring to influence the future, he simply lies down and lets things happen to him. During the past ten years literature has involved itself more and more deeply in politics, with the result that there is now less room in it for the ordinary man than at any time during the past two centuries. (CW XII 91) 
It is possible to speculate that, without the outbreak of war, the essay would have generated the voice of the ordinary man as pacifist - rather as in Orwell's novel Coming Up for Air. However, once having accepted the necessity of war, Orwell was no longer able to do this. But he kept his commitment to his own branch of $30 \mathrm{~s}$ radicalism by insisting that the example of Miller was not the starting-point of a new school of literature, but "a demonstration of the impossibility of any major literature until the world has shaken itself into its new shape" (CW XII 112).

It is this particular assertion which Rushdie takes as conclusive proof of Orwell's apostasy, ironically commenting: "And we are told that fatalism is a quality of Indian thought" (95). However, the logic behind Orwell's seemingly straightforward claim is considerably more complex than Rushdie allows. A reading of Orwell's radio discussion of "The Proletarian Writer", broadcast in December 1940, allows us to understand the apparent paradox. Here, Orwell argues, like Trotsky, 'I don't believe the proletariat can create an independent literature while they are not the dominant class" ( $C W$ XII 295). However, he goes on to qualify this position:

So long as the bourgeoisie are the dominant class, literature must be bourgeois. But I don't believe that they will be dominant much longer, or any other class either. I believe we are passing into a classless period, and what we call proletarian literature is one of the signs of change. ( $C W$ XII 297)

Read back, this suggests that in "Inside the Whale", Orwell was trying to argue not only that the voice of the ordinary man necessarily appeared passive because it was expressed against the active domination of the bourgeoisie, but also that the extent to which, nonetheless, Miller (and proletarian writers and Orwell himself) had been 
successful in giving a voice to the ordinary man signified the waning of this bourgeois domination. From this perspective, ending on a note of the impossibility of major literature is not fatalistic, but optimistic.

Finally, Rushdie tells us that Orwell, who fully understands Miller's retreat inside the whale as a retreat inside the womb, "embraces and espouses this quietist philosophy" by encouraging us to " "Get inside the whale - or rather, admit you are inside the whale (for you are of course)" " (95). However, this injunction to "get inside the whale, accept it, endure it" is, I would suggest, ironic: "Seemingly there is nothing left but quietism" writes Orwell, "That seems to be the formula that any sensitive novelist is now likely to adopt" (emphasis added, $C W$ XII 111). But it is not a single critical irony, rather a double irony that accepts the convention with no intention of actually abiding by it. Orwell had explicitly written in Coming Up for Air (1939) that "you can't put Jonah back in the whale" ( $C W$ VII 237). So he knew such a retreat was not possible, but by playing off Miller against the "Auden Generation", which is what the essay is about, he was trying to create a dialectical space in which the politics of locality, human albeit passive, could interact with a wider political imaginary. Such a space is recognisable according to theoretical models of everyday life, in which the historical memory of class consciousness combines with the utopian promise of the future in order to contest the regulating processes of capitalist everydayness (see Roberts 16-29).

Perhaps the most significant aspect of these misreadings is their cumulative effect to the detriment of Rushdie's argument. For example, Aijaz Ahmad has praised Rushdie's "superb critique of Orwell” but despaired that even despite this Rushdie still seems to share a world-weary Orwellian view of history and politics (155-6). Yet what Rushdie really shares with Orwell is the same unorthodox mixture of journalistic 
polemic and literary technique that generates a complexity of argument through levels of irony in the narrative tone rather than through the abstract theorizing more common in the academic world. By showing Rushdie to have misinterpreted Orwell, it is possible to redeem their shared approach by focusing on them not as writers standing alone against the totalitarian force of history, but as writers creating a dialectical space in their work - creating some sort of "whale" - and thus gaining purchase on an "unceasing storm" that has not yet become history.

The greater irony behind the shared failure of Anderson and Rushdie to appreciate the dialectical quality of Orwell's thought is that this quality originated in his colonial background - the factor that draws him into the postcolonial spotlight in the first place. As the passage from Wigan Pier quoted earlier demonstrates, the appeal to Orwell of joining the Imperial Police was that it reconciled the dual perspective resulting from being simultaneously poor and a gentleman. However, Orwell's account is perhaps disingenuous as it highlights the economic anomaly of his lowerupper-middle class position rather than his romanticism and idealism, which were necessary ideological components of his youthful imperialist stance. This can be seen from his eventual inability in practice to maintain the schizophrenic illusion of Burma as simultaneously worthy of rule by gentlemen and a site of economic exploitation. It was the impossibility of maintaining his idealism under these circumstances that led to his rejection of imperialism and forced him to seek the dialectical resolution of his inherited dual perspective elsewhere - and where else but England? Orwell's colonial family background and his birth in India were factors which bred a shared idealistic belief in Empire and, above all, in the "home country", England: a set of attitudes articulated in Kipling's notion of "who dies if England live?" which as we have seen remained central to Orwell's thought even in the revolutionary ferment of 1940. 
However, this is not to say that Orwell's work following his return from Burma simply reflects a transfer of allegiance from an idea of Empire to an idea of England. Rather we can see his initial evocation of ordinary England as the literary creation of an imaginary homeland: the formation of a dialectical space in which the nascent writer would be able to gain a purchase on the flux of history in general and the dynamic of imperialism in particular, as stated in Wigan Pier: "I felt that I had got to escape not merely from imperialism but from every form of man's dominion over man. I wanted to submerge myself right down among the oppressed, to be one of them and on their side against the tyrants" ( $C W \mathrm{~V} 138)$. Nevertheless, he knew perfectly well that he could not divorce himself from his class background: "in real life nobody ever does that kind of thing ..." ( $C W \mathrm{~V}$ 140). But he could do it by writing under the very English pseudonym of "George Orwell" about being down and out.

The true significance of Orwell's career lies in the way he was able to transform this personal imaginary homeland into a political imagined community. The process begins at the end of Wigan Pier with the offering of his literary classless persona as a point of identification to a real middle-class readership with the injunction "we have nothing to lose but our aitches" ( $C W \mathrm{~V} 215)$. It reaches its culmination in The Lion and the Unicorn with its powerful projection of a classless England as a future worth fighting for:

The place to look for the germs of the future England is in the light-industry areas and along the arterial roads. In Slough, Dagenham, Barnet, Letchworth, Hayes everywhere, indeed, on the outskirts of great towns - the old pattern is gradually changing into something new. In those vast new wildernesses of glass and brick the 
sharp distinctions of the older kind of town, with its slums and mansions, or of the country, with its manor-houses and squalid cottages, no longer exist. There are wide gradations of income, but it is the same kind of life that is being lived at different levels, in the labour-saving flats or Council houses, along the concrete roads and in the naked democracy of the swimming pools. (CW XII 408)

Another way of thinking about Orwell's history would be to see it as the outcome of somebody having to imagine a national identity for their "home" country because of neither belonging by birth nor being able to accept the economic and political ties that connected their birth places to that "home" country. As such, I would argue that this process is the reversal of that described by Anderson in which the idea of nationalism originated with the Creole populations of the Americas, who were not indigenous but wished to be no longer tied to the centres of Empire from which they had originated (47-65). The result of this reverse process undergone by Orwell was not the fixed Englishness of a narrow patriotism but the projection of an imagined community intended to transcend national self-interest in favour of a wider loyalty to humanity. The eradication of the domestic class system was to be linked to the eradication of racism and colonialism as suggested by the fourth item in the six-point programme advanced by Orwell in the third part of The Lion and the Unicorn: "Immediate Dominion status for India, with power to secede when the war is over" ( $C W$ XII 422).

Of course, the domestic realities of the 1945 settlement and the subsequent postwar British Welfare State turned out to be very different from Orwell's vision. But at a time when the ongoing 'break-up' of Britain - as witnessed by both the devolution of power to the constituent nations and the accelerated erosion of the collective values embodied in the Welfare State - and the reemergence of 'the English question' are 
giving rise to anxieties concerning the future of cultural and ethnic diversity in England, it is useful to remember that there is a version of postcolonial Englishness ready to hand in Orwell's work. Perhaps, though, the wider significance of Orwell now lies in the way in which he can be read as a precursor to both Anderson and Rushdie and, more importantly, as the third participant in a discourse that links the literary writer's need for an imaginary homeland with the enduring political need for the self-sacrifice and openness of the imagined community as a staging point on the road to a globally shared sense of humanity.

\section{Works Cited}

Ahmad, Aijaz. In Theory: Classes, Nations, Literatures. London: Verso, 1994

Anderson, Benedict. Imagined Communites: Reflections on the Origin and Spread of Nationalism. London: Verso, 1991.

Auden, W.H. The English Auden: Poems, Essays and Dramatic Writings 1927-1939. Ed. Edward Mendelson. London: Faber and Faber, 1986.

Coombes, John. “A New Dissection of Orwell's Elephant.” 1936: The Sociology of Literature, vol. 2: Practices of Literature and Politics. Eds Francis Barker et al. Colchester: University of Essex, 1979.

Orwell, George. The Complete Works of George Orwell, 20 volumes. Ed. Peter Davidson. London: Secker \& Warburg, 1998.

Roberts, John. "Philosophising the Everyday: The Philosophy of Praxis and the Fate of Cultural Studies.” Radical Philosophy 98 (1999): 16-29.

Rushdie, Salman. Imaginary Homelands: Essays and Criticism 1981-1991, Harmondsworth: Granta Books/Penguin, 1991. 
Said, Edward. Orientalism, New York: Vintage Books, 1979. 